UNCLASSIFIED

Geology - Mineralogy

This document consists of 27 pages, plus 1 figure.

Series A

UNITED STATES DEPARTMENT OF THE INTERIOR

GEOLOGICAL SURVEY

RECONNAISSANCE FOR RADIOACTIVE DEPOSITS IN THE NIXON FORK

MINING DISTRICT, MEDFRA QUADRANGLE,

CENTRAL ALASKA, 1949*

By

Max G. White and John M. Stevens

February 1953

Trace Elements Investigations Report 75

This preliminary report is distributed without editorial and technical review for conformity with official standards and nomen-

clature. It is not for public inspection or quotation.

*This report concerns work done on behalf of the Division of Raw Materials of the U. S. Atomic Energy Commission 
USGS - TEI Report 75

GEOLOGY - MINERALOGY

Distribution (Series A)

No. of copies

American Cyanamid Company, Winchester .......... 1

Argonne National Laboratory ................ 1

Atomic Energy Commission, Washington .......... 2

Battell le Memotial Institute, Columbus ............ 1

Carbide and Carbon Chemicals Company, Y-12 Area ..... 1

Division of Raw Materials, Grants . . . . . . . . . . 1

Division of Raw Materials, Denver ............. 1

Division of Raw Materials, Hot Springs ........... 1

Division of Raw Materials, New York ..........66

Division of Row Materials, Salt Lake City .......... 1

Division of Raw Materials, Richfield ........... 1

Division of Raw Materials, Butte ............. 1

Division of Raw Materials, Washington ........... 3

Dow Chemicál Company, Pittsburg .............. 1

Exploration Division, Grand Junction Operations Office .... 1

Grand Junction Operations Office ............. I

Technical Imformation Service, Oak Ridge .........6

Tennessee Valley Authority, Wilson Dam .......... 1

Terr. Dept. Mines, Juneau (P. H. Holdsworth) ......... I

Terr. Dept. Mines, Ketchikan (A. E. Glover) ........ I

Terr. Dept. Mines, College (L. L. Patton) ........ 1

Terr. Dept. Mines, Nome (D. Jones) . . . . . . . . . . I

U. S. Geological Survey:

Mineral Deposits Branch, Washington ............ 1

Geochemistry and Petrology Branch, Washington ....... 1

Geophysics Branch, Washington .............. I

Alaskan Geology Branch, Washington ........... 8

G. O. Gates, San Francisco . . . . . . . . . . 2

L."H. Saarela, Anchorage . ............. I

C. L. Sainsbury, Juneau ................ 1

R. M. Chapman, Fairbanks ............... I

V. E. Mc Kelvey, Washington .............

L. R. Page,"Denver . . . . . . . . . . . . . 1

R. P. Fischer, Grand Junction ............... 1

A. E. Weissenborn, Spokane .............. . 1

TEPCO, Washington ................ . . 5

(Including master) 
CONTENTS

Abstract ...................... 5

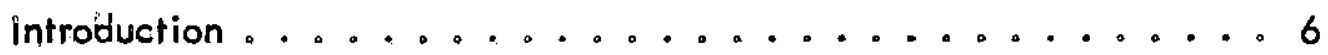

Geology, mineral deposits, and radioactivity investigations ... 8

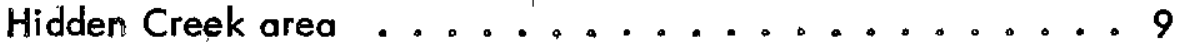

Whalen mine .................... 9

Ruby Creek area . . . . . . . . . . . . . . 14

Nixon Fork mine ............... . 18

Crystal shaft .............. 18

Other localities examined .............. 22

Mystery, Puzzle and Submarine Creeks ....... 22

Eagle Creek. ................. 22

Summary and conclusions ................. 24

Literature cited . . . . . . . . . . . . . 27

\section{ILLUSTRATION}

Figure 1. Geologic sketch map of the vicinity of the Nixon

Fork mines ............... in envelope

\section{TABLES}

Table 1. Data on concentrates collected in the Nixon Fork mining district before $1949 \ldots \ldots . \ldots 7$

2. Data on placer concentrates collected from Hidden Creek and its tributaries in $1949 \ldots \ldots \ldots$

3. Data on samples collected from the Whalen mine and vicinity .................... 12

4. Data on bedrock samples and concentrates collected in the Ruby Creek area in 1949 . . . . . . . . . 15

5. Mineralogy and radioactivity of three placer concentrates from the Nixon Fork mining district . . . . . . . 17

6. Data on ore, mill, and tailings samples from the Nixon

Fork mine, 1949 . . . . . . . . . . . . . 19 
TABLES (continued)

Page

Table 7. Data on samples of garnet rock from the vicinity of

the Crystal shaft, Nixon Fork mine . . . . . . 21

8. Summary of significant radioactivity data obtained in the

Nixon Fork mining district, $1949 \ldots \ldots$. . . . . 25 


\title{
RECONNAISSANCE FOR RADIOACTIVE DEPOSITS IN THE NIXON FORK MINING DISTRICT, MEDFRA QUADRANGLE, CENTRAL ALASKA, 1949
}

By Max G. White and John M. Stevens

\begin{abstract}
Reconnaissance for radioactive deposits in the Nixon Fork mining district, Medfra quadrangle, central Alaska, in 1949 disclosed the occurrence of allanite in samples containing as much as 0.05 percent equivalent uranium from the dump of the Whalen mine; the presence of radioactive parisite (a rare-earth fluocarbonate) in a highly altered limestone containing about 0.025 percent equivalent uranium near the Whalen shaft; and radioactive idocrase in samples of altered garnet rock with about 0.025 percent equivalent uranium, from the Crystal shaft of the Nixon Fork mine. This radioactivity is due mostly to thorium rather than uranium. Placer concentrates from Ruby and Eagle Creeks contain 0.078 and 0.26 percent equivalent uranium respectively, in which the radioactivity is due chiefly to uraniferous thorianite. The bedrock source of the uraniferous thorianite was not located primarily because much of the area is overlain by a relatively thick mantle of vegetation (mostly moss) which limited the effectiveness of radiometric surveying. The uraniferous thorianite is believed to occur in a restricted zone or zones at or near the contact of limestone with monzonite similar to the gold-copper ores of the district and the deposits of radioactive parisite and garnet rock at the Whelan and Crystal shafts respectively.
\end{abstract}




\section{INTRODUCTION}

The Nixon Fork mining district (fig. 1) is in a low range of hills of the Kuskokwim Mountains, about 12 miles north of Medfra, a small settlement on the Kuskokwim River 95 miles upstream from McGrath, in central Alaska. Access to the area is by boat or airplane from McGrath to Medfra, and from Medfra to the mines by truck.

The term "Nixon Fork mines" has long been used for both lode and placer mines in the district. Most of the lode-mining property is held by the Nixon Fork Mining Co., whose principal owners are the Mespelt brothers of McGrath. Their property is called the Nixon Fork mine. The only other lode-mining property of any importance is the Whalen mine, adiacent to and south of the Nixon Fork mine property.

Some of the radioactive placer concentrates from the Nixon Fork mining district available in the Geological Survey's Alaskan Geology Branch placer concentrate file before 1949 (table 1) contain uraniferous thorianite associated with bismuth and copper minerals. This association suggested that the district was favorable for the occurrence of a uranium-bearing lode deposit. Therefore, in 1949, a Geological Survey party conducted a reconnaissance in the district to determine its uranium possibilities. Approximately three weeks were required for the investigation, of which one and a half days were spent at a gold-lode prospect on Eagle Creek, about 5 to 7 miles south of the main Nixon Fork mines (fig. 1). The party consisted of M. G. White and J. M. Stevens, geologists, and Egil Salveson and R. D. Olson, camp assistants. This work was done on behalf of the Division of Raw Materials of the U. S. Atomic Energy Commission. 
Table 1.--Data on concentrates collected in the Nixon Fork mining district before 1949.

Samples

File no. Field no.

Location and description

Percent equivalent

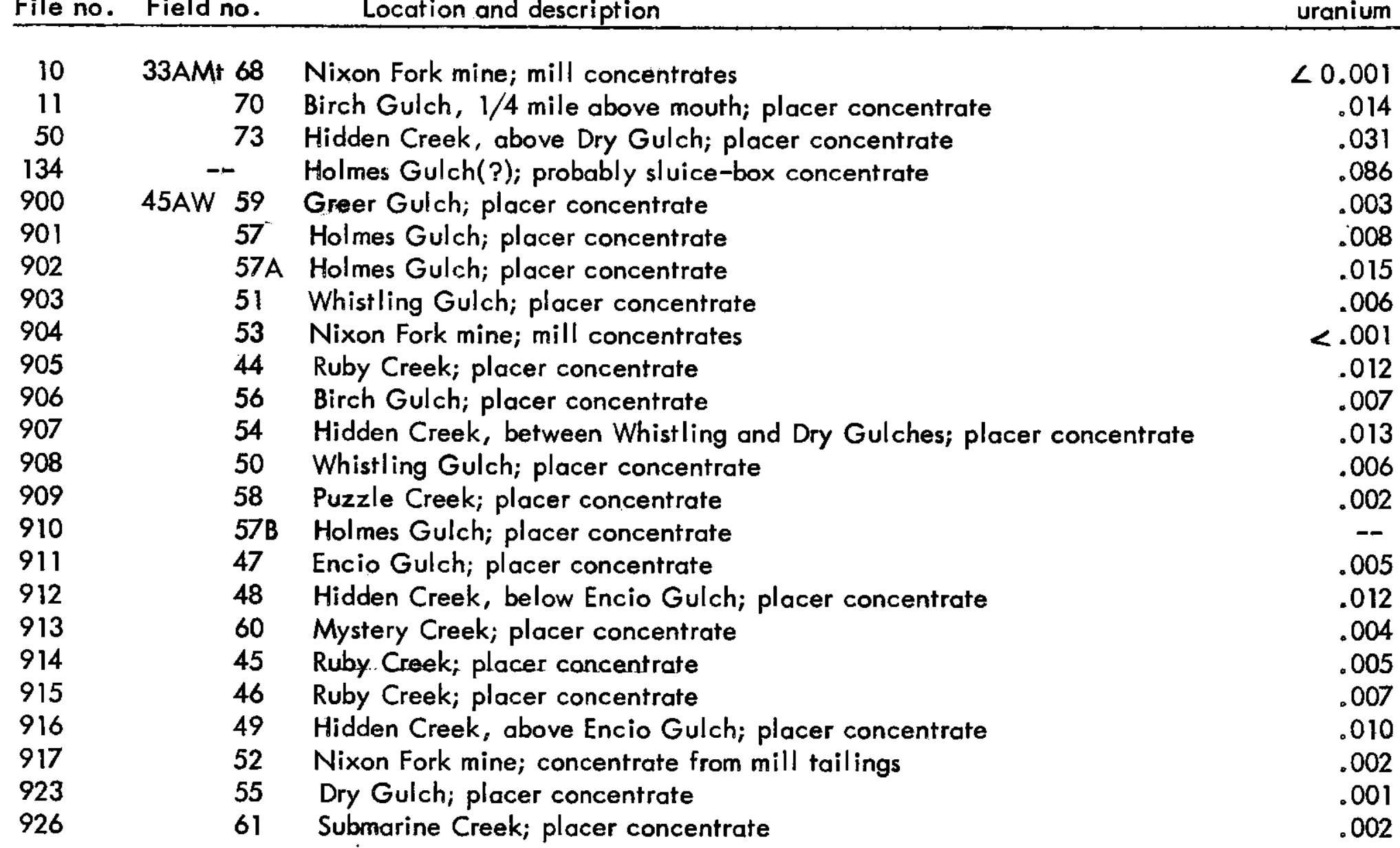




\section{GEOLOGY, MINERAL DEPOSITS, AND RADIOACTIVITY INVESTIGATIONS}

The low range of hills on which the Nixon Fork mines are located is composed of Paleozoic limestone and Upper Cretaceous sandstone, shale, and slate. The rocks are intruded by quartz monzonite that is probably Eocene in age. The lode deposits in the district are an enrichment in limestone along contact metamorphic zones between the limestone and monzonite. Most of the mineral deposits are apparently restricted to the valleys of the tributaries of Hidden Creek and the slopes around the north headwater fork of Ruby Creek (fig. 1). No mineral deposits of any note have been found along the eastern edge of the monzonite.

Placer gold was found on Ruby Creek in the winter of 1917, and shortly thereafter, the lode deposits at the head of Crystal Gulch were located. In 1920 a $10-$ stamp mill was installed at the head of Ruby Creek to process the highly oxidized copper-gold ores from the various shafts and prospects in the district. Mining and milling has been carried on in the district intermittantly since 1920 .

More detailed descriptions of the geology, mineral deposits, and mining of the Nixon Fork district are contained in reports by Martin (1922), Brown (1926), and Mertie (1936).

As is the case with much of interior Alaska, the area around the Nixon Fork mines is thickly covered with underbrush of willow, alder, spruce and birch, and by moss, which averages about 3 feet in thickness. These conditions make the results of radiometric traversing at best inconclusive, except in the localities where recent mining developments have uncovered sufficient bedrock for direct examination.

The mineral deposits on the properties of the Nixon Fork Mining Co. and at the Whalen mine contain both copper and gold, and occur along the contact between 
the limestone and monzonite. The highly mineralized part of the contact zone is exposed by a large number of shafts and prospect pits, and, hence, was examined in some detail. Much of the remainder of the contact could not be examined because of the moss cover.

\section{Hidden Creek area}

Some of the samples in the Nixon Fork district with the greatest concentration of thorianite come from Encio Gulch, a tributary of Hidden Creek (fig. 1). However, radiometric traverses around the head of Hidden Creek and its headwater tributaries gave negative results. The results are negative, not so much because of the lack of any radioactive materials, which may be perfectly possible, but probably because the valley is covered almost completely by a thick shielding cover of moss and low brush. Concentrates from stream gravels collected during the 1949 investigations are listed in table 2. They are somewhat lower in radioactivity than the pre-1949 samples because the latter were obtained when placer operations were active in the valley. The occurrence of bismuth in the placers is apparently restricted to the valley of Hidden Creek above Dry Gulch, and, because it is thought that all of that portion of the valley of Hidden Creek is underlain by monzonite, it is likely that the bismuth is restricted to the monzonite.

\section{Whalen mine}

The main shaft of the Whalen mine is located at the head of Homes Gulch very near the contact between the limestone and monzonite. The limestone forms an island surrounded by monzonite (fig. 1). At this shaft boulders of limestone on the waste 
Table 2.--Data on placer concentrates collected from Hidden Creek and its tributaries in 1949.

\begin{tabular}{|c|c|c|c|c|}
\hline Sale no. & $\begin{array}{l}\text { nples } \\
\text { Field no. }\end{array}$ & Location & $\begin{array}{l}\text { ncentration } \\
\text { ratio }\end{array}$ & $\begin{array}{l}\text { Percent equivalent uranium in } \\
\text { heavy-mineral fraction }\end{array}$ \\
\hline 3574 & 49ASv 108 & Hidden Creek, above Encio Gulch & 145:1 & 0.009 \\
\hline 3575 & 109 & $\begin{array}{l}\text { Hidden Creek, left limit tributary above } \\
\text { Encio Gulch }\end{array}$ & 400: 1 & .006 \\
\hline 3576 & 110 & $\begin{array}{l}\text { Hidden Creek, extreme head, 1,000 feet } \\
\text { below road }\end{array}$ & 120:1 & .006 \\
\hline 3577 & 111 & Do. & 310:1 & .007 \\
\hline 3578 & 112 & Hidden Creek, prospect hole & 275: 1 & .006 \\
\hline 3579 & 113 & Birch Gulch, 1,000 feet above mouth & $360: 1$ & .012 \\
\hline 3580 & 114 & Dry Gulch, 1,500 feet above mouth & $630: 1$ & .003 \\
\hline 3581 & 115 & Hidden Creek, 1/2 mile above Birch Gulch & $150: 1$ & .005 \\
\hline 3582 & 116 & $\begin{array}{l}\text { Hidden Creek, } 1 / 2 \text { mile above Birch Gulch; } \\
\text { tailings pile }\end{array}$ & $90: 1$ & .005 \\
\hline 3583 & 117 & Whistling Gulch, near mouth & 190:1 & .007 \\
\hline 3584 & 118 & Holmes Gulch, left headwaters fork & $270: 1$ & .005 \\
\hline 3584 & 119 & Encio Gulch, left headwaters fork & $60: 1$ & .004 \\
\hline 3585 & 120 & Encio Gulch, right headwaters fork & $90: 1$ & .005 \\
\hline 3586 & 121 & Encio Gulch, near mouth & $80: 1$ & .006 \\
\hline
\end{tabular}


dump are radioactive and contain a high percentage of a black mineral. The equivalent uranium content of the boulders is 0.05 percent, but fluorometric analysis indicates a uranium content of only 0.004 percent (table 3). It is assumed, therefore, that most of the radioactivity of these rocks is due to thorium. The heavy-mineral concentrate (that greater than 2.8 specific gravity) of the rock consists of 98 percent allanite (the radioactive mineral) and 2 percent zircon, kyanite and scheelite. These heavy minerals constitute about 25 percent of the rock.

A short distance east of the main shaft is a large depression about 40 feet deep formed as the result of a cave-in on the 40 -foot level of the mine. Most of the material of the cave-in was high-grade gold ore and was mined out, leaving a "glory hole". Along the walls of the glory hole is exposed highly weathered metamorphic rock consisting mainly of quartz and limestone that has an average content of about 0.025 percent equivalent uranium (table 3). However, chemical analyses show only 0.002 percent uranium in this rock. The radioactive mineral is parisite (a rare-earth fluocarbonate) that makes up about 95 percent of the heavy-mineral fraction of the rock.

The main shaft of the Whaten mine is 200 feet deep and is inclined at an 85 degree angle down the contact. This shaft could not be examined because it was filled with ice to within 12 feet of the top.

There are between 150 and 200 small shafts and prospect pits along the contact between the limestone and monzonite in the vicinity of the Whalen mine. Approximately 80 of the prospect pits were cleaned out and tested radiometrically in an effort to discover any additional concentrations of radioactive minerals. A few of the holes tested have a higher than normal radioactivity and were sampled for further study (table 3). Radiometric analyses of these samples indicate an equivalent uranium content ranging from 0.001 to 0.006 percent (table 3 ). The radioactive 
Table 3.--Data on samples collected from the Whalen mine and vicinity

\begin{tabular}{|c|c|c|c|c|c|c|}
\hline \multirow{2}{*}{\multicolumn{2}{|c|}{ Samples }} & \multirow[b]{3}{*}{ Location and description } & \multicolumn{2}{|c|}{ Crushed rock } & \multicolumn{2}{|c|}{ Heavy-mineral fraction } \\
\hline & & & eU $1 /$ & U 2/ & eU & Concentration \\
\hline File no. & Field no. & & (percènt) & (percent) & (percent) & ratio \\
\hline
\end{tabular}

\section{Samples collected at Whalen mine}

\begin{tabular}{|c|c|c|c|c|c|c|}
\hline 3619 & 49AWe 127 & $\begin{array}{l}\text { Whalen mine tailings dump; limestone with } \\
\text { large amount of metamorphic minerals }\end{array}$ & 0.05 & 0.004 & 0.081 & $4: 1$ \\
\hline 3620 & 128 & $\begin{array}{l}\text { Same as sample } 3619 \text {; concentrate from } \\
\text { panning crushed rock }\end{array}$ & -- & -- & .08 & $4: 1$ \\
\hline 3621 & 129 & $\begin{array}{l}\text { Whalen mine "glory hole"; wash from } \\
\text { west side rim }\end{array}$ & -- & -- & .06 & 900: 1 \\
\hline 3622 & 130 & $\begin{array}{l}\text { "Glory hole"; rock along contact between } \\
\text { highly weathered limestone and highly } \\
\text { leached limestone, panned concentrate }\end{array}$ & -- & -- & .14 & 850: 1 \\
\hline 3623 & 132 & $\begin{array}{l}\text { Same as sample } 3622 \text {; highly weathered } \\
\text { limestone }\end{array}$ & .03 & .002 & .14 & 35: 1 \\
\hline 3624 & 133 & Same as 3623 ; panned concentrate & -- & -- & .14 & 160:1 \\
\hline 3625 & 134 & Same as 3622 ; weathered limestone & .02 & .002 & .10 & 400:1 \\
\hline 3626 & 135 & $\begin{array}{l}\text { "Glory hole".i combination of the rock } \\
\text { types of samples } 3623 \text { and } 3625\end{array}$ & .03 & .002 & .12 & $30: 1$ \\
\hline 3627 & 150 & $\begin{array}{l}\text { Slope east of Whalen mine shaft; decom- } \\
\text { posed limestone; panned concentrate }\end{array}$ & -- & -- & .019 & $2,400: 1$ \\
\hline 3628 & 151 & Same as sample 3627 ; unconcentrated rock & .005 & .002 & .04 & 640: 1 \\
\hline
\end{tabular}


Table 3.--Data on samples collected from the Whalen mine and vicinity--Continued.

\begin{tabular}{|c|c|c|c|c|c|}
\hline \multirow{2}{*}{\multicolumn{2}{|c|}{ Samples }} & \multicolumn{2}{|c|}{ Crushed rock } & \multicolumn{2}{|c|}{ Heavy-mineral fraction $3 /$} \\
\hline & & eU $V$ & U $2 /$ & eU & Concentration \\
\hline
\end{tabular}

Samples collected from some of the prospect holes along the contact between the monzonite and limestone in the vicinity of the Whalen mine.

\begin{tabular}{|c|c|c|c|c|c|c|}
\hline 3629 & 49AWe 153 & Hole no. 21 ; limestone & 0.004 & -- & 0.010 & $170: 1$ \\
\hline 3630 & 154 & Hole no. 24 ; monzonite & .003 & -- & .010 & $90: 1$ \\
\hline 3631 & 155 & Hole no. 25 ; monzonite & .003 & -- & .004 & 40:1 \\
\hline 3632 & 156 & Hole no. 32 ; limestone & .000 & -- & .001 & 50:1 \\
\hline 3633 & 157 & Hole no. 51; limestone & .002 & -- & .004 & $40: 1$ \\
\hline 3634 & 158 & Hole no. 52; limestone & .006 & -- & .018 & $20: 1$ \\
\hline 3635 & 159 & Hole no. 54 ; monzonite & .002 & - & .004 & $20: 1$ \\
\hline 3636 & 160 & Hole no. 56; monzonite & .003 & -- & .008 & 50:1 \\
\hline 3637 & 161 & Hole no. 60 ; monzonite & .001 & -- & .003 & $25: 1$ \\
\hline 3638 & 162 & Hole no. 61; limestone & .005 & $=$ & .019 & 300: 1 \\
\hline 3639 & 163 & Hole no. 65 ; monzonite & .001 & -- & .003 & 30: 1 \\
\hline 3640 & 164 & Hole no. 68 ; limestone & .004 & - & .006 & $60: 1$ \\
\hline 3641 & 164 & Hole no. 74 ; monzonite & .005 & - & .007 & 25: 1 \\
\hline
\end{tabular}

1/ eU - equivalent uranium

2) U-uranium

3/ that greater than 2.8 specific gravity 
minerals in these samples are allanite, hematite, zircon, and sphene.

\section{Ruby Creek area}

Samples from Ruby Creek are not plotted on figure 1, but their locations are described in table 4. The most radioactive sample obtained in the Ruby Creek drainage (no. 3570 , table 4) contains 0.078 percent equivalent uranium. The sample is a sluice-box concentrate from the Strand placer mine on Ruby Creek at the foot of the headwaters gradient of Crystal Gulch. Most of the lode deposits on the Nixon Fork Mining Co. property are located at the head of this gulch. The percentages of the minerals in the fraction greater than 2.8 specific gravity of this concentrate are given in table.5. Most of the radioactivity in this sample is probably due to the thorianite. The unknown secondary minerals were analysed spectrographically. The yellow mineral contains bismuth, lead, copper, iron, vanadium, and silicon as major constituents, and calcium, aluminum, arsenic and antimony as minor constituents. The green mineral contains copper, bismuth, silicon, calcium, iron, and lead as major constituents, and aluminum, vanadium and phosphorous as minor constituents. The source of neither the thorianite nor the secondary uranium-bearing minerals was found, though search was extended to all the slopes of Ruby Creek along the confact and in the monzonite, where these slopes were not thickly covered by moss. It is possible that these minerals are derived from a restricted zone at or close to the contact, much as the parisite-bearing zone at the contact in the Whalen mine "glory hole". The radioactivity in all the concentrates and rock samples from the head of Ruby Creek is probably due mainly to the minerals zircon and sphene as thorianite was not found in them. 
Table 4.--Data on bedrock samples and concentrates collected in the Ruby Creek area in 1949.

\begin{tabular}{|c|c|c|c|c|c|c|c|}
\hline \multirow{2}{*}{\multicolumn{3}{|c|}{ Samples }} & \multirow[b]{3}{*}{ Location and description } & \multicolumn{2}{|c|}{ Crushed rock } & \multicolumn{2}{|c|}{ Heavy-mineral fraction $3 /$} \\
\hline & & & & eU $1 /$ & U $2 /$ & & Concentration \\
\hline File no. & - Field & no. & & (percent) & (percent) & (percent) & ratio \\
\hline 3558 & 49ASV & 91 & $\begin{array}{l}\text { Head of Ruby Creek; placer concentrate } \\
\text { above mill and mill tailings dump }\end{array}$ & -- & -- & 0.007 & 300:1 \\
\hline 3567 & & 100 & $\begin{array}{l}\text { Ruby Creek; placer concentrate at foot of } \\
\text { headwaters gradient }\end{array}$ & -- & - & .006 & $130: 1$ \\
\hline 3568 & & 101 & Same as sample 3567 & -- & -- & .008 & 290:1 \\
\hline 3569 & & 102 & $\begin{array}{l}\text { Crystal Gulch; concentrate from head of } \\
\text { placer workings }\end{array}$ & -- & - & .02 & $650: 1$ \\
\hline 3570 & & 103 & $\begin{array}{l}\text { Ruby Creek; slulce-box concentrate from } \\
\text { Strand placer workings }\end{array}$ & -- & -- & .078 & very high \\
\hline 3593 & 49AWe & 89 & $\begin{array}{l}\text { Along trail on left limit of Crystal Gulch; } \\
\text { monzonite }\end{array}$ & 0.004 & -- & .005 & $15: 1$ \\
\hline 3594 & & 91 & $\begin{array}{l}\text { Along rood from mill to Garnet Shaft; } \\
\text { monzonite }\end{array}$ & .003 & -- & .006 & 9:1 \\
\hline 3596 & & 94 & $\begin{array}{l}\text { Bench on right limit of Ruby Creek above } \\
\text { Strand placer mine; disintegrated monzonite }\end{array}$ & -- & -- & .011 & 690:1 \\
\hline 3597 & & 95 & Same as sample 3596 ; undisintegrated rock & .003 & -- & .005 & $10: 1$ \\
\hline 3598 & & 97 & $\begin{array}{l}\text { At mouth of Crystal Gulch in Strand placer } \\
\text { mine; shattered monzonite }\end{array}$ & -- & -- & .004 & $650: 1$ \\
\hline 3599 & & 98 & $\begin{array}{l}\text { On north side of Strand placer mine; panned } \\
\text { concentrate from disintegrated granitic } \\
\text { dike in monzonite }\end{array}$ & -- & -- & .013 & $2,270: 1$ \\
\hline 3600 & & 99 & $\begin{array}{l}\text { Same as sample 3599; quartz veins paralleling } \\
\text { granitic dike }\end{array}$ & .002 & -- & .010 & $220: 1$ \\
\hline
\end{tabular}


Table 4.--Data on bedrock samples and concentrates collected in the Ruby Creek area in 1949--Continued.

\begin{tabular}{|c|c|c|c|c|c|c|}
\hline \multirow{2}{*}{\multicolumn{2}{|c|}{ Samples }} & \multirow[b]{3}{*}{ Location and description } & \multicolumn{2}{|c|}{ Crushed rock } & \multicolumn{2}{|c|}{ Heavy-mineral fraction 3/ } \\
\hline & & & eU I/ & U 2/ & & Concentration \\
\hline File no. & Field no. & & (percent) & (percent) & (percent) & ratio \\
\hline 3601 & 49AWe 101 & $\begin{array}{l}\text { On south side of Strand placer mine; panned } \\
\text { concentrate of disintegrated granitic dike }\end{array}$ & - & -- & 0.032 & $780: 1$ \\
\hline 3602 & 102 & Same as sample 3601 ; undisintegrated rock & 0.003 & -- & .016 & 80: 1 \\
\hline 3603 & 104 & Strand placer mine; inclusions in monzonite & .002 & -- & .003 & $5: 1$ \\
\hline 3604 & 105 & $\begin{array}{l}\text { Middle Crystal Gulch; bedrock from contact } \\
\text { zone }\end{array}$ & .002 & -- & .007 & $70: 1$ \\
\hline 3607 & 111 & $\begin{array}{l}\text { Same as sample } 3594 \text {; panned concentrate } \\
\text { from disintegrated monzonite }\end{array}$ & -- & -- & .015 & $1,800: 1$ \\
\hline 3608 & 112 & $\begin{array}{l}\text { Same as sample 3594; panned concentrate } \\
\text { of disintegrated granitic dike in monzonite }\end{array}$ & -- & -- & .033 & $2,270: 1$ \\
\hline 3609 & 113 & $\begin{array}{l}\text { Same as sample } 3594 \text {; undisintegrated } \\
\text { granitic dike in monzonite }\end{array}$ & .008 & 0.004 & .021 & $100: 1$ \\
\hline
\end{tabular}


Table 5. --Mineralogy and radioactivity of three placer concentrates from the Nixon Fork mining district.

Minerals

Allanite

Azurite

Cassiterite

Common rock-forming minerals

Fluorite

Garnet

Gold

Hematite

llmenite

Malachite

Magnetite

Monazite

Powellite

Pyrite

Scheelite

Sphene

Thorianite

Unknown secondary green mineral

Unknown secondary yellow mineral

Uraninite

Zircon

\begin{tabular}{|c|c|c|}
\hline $\begin{array}{c}\text { Sample no. } \\
3570 \\
\end{array}$ & $\begin{array}{c}\text { Sample no. } \\
3642 \\
\end{array}$ & $\begin{array}{c}\text { Sample no. } \\
3850 \\
\end{array}$ \\
\hline-- & $3 * 1 /$ & $1^{*}$ \\
\hline tr & -- & -- \\
\hline 3 & -- & -- \\
\hline 4 & 2 & -- \\
\hline tr & 1 & tr \\
\hline-- & 5 & 4 \\
\hline a 2/ & -- & -- \\
\hline$a^{*-}$ & $t r^{*}$ & -- \\
\hline 70 & 85 & 80 \\
\hline$t r^{*}$ & -- & - \\
\hline 13 & tr & 8 \\
\hline-- & -- & tr \\
\hline- & -- & tr \\
\hline-- & -- & tr \\
\hline 5 & 3 & 4 \\
\hline$a^{*}$ & $t r^{*}$ & -- \\
\hline$a^{*}$ & $1^{*}$ & $1^{*}$ \\
\hline$t r^{*}$ & -- & -- \\
\hline$t r^{*}$ & -- & -- \\
\hline-- & -- & $1^{*}$ \\
\hline$a^{*}$ & $t r$ & tr \\
\hline
\end{tabular}

Equivalent uranium content (percent) Uranium content (percent)
0.078

n.d.
0.26

n.d.
0.18

.06

1/ Estimated volume percent; the asterisk indicates that the mineral is uraniumbearing as determined by a sodium fluoride flux test.

2) a indicates that these five minerals total 5 percent of the sample. 


\section{Nixon Fork mine}

Almost all the ore that was processed from all the shafts and prospect pits in the vicinity of the Nixon Fork mine was processed at the stamp mill located at the head of Ruby Creek (fig. 1). The tailings from the milling operation, crushed to fine silt size, were dammed up at the rear of the mill in the expectation that with further refinement of the milling processes additional gold could be recovered from these tailings. Radiometric tests of these tailings in the field indicated no appreciable radioactivity. However, in order to determine whether any radioactive minerals had been carried over into the tailings during milling operations, the mill tailings pile was sampled both across the surface or top (with holes 3 to 4 feet deep) and across the base. As the equivalent uranium content of the heavy-mineral fractions (those greater than 2.8 specific gravity) of these samples ranges only from 0.002 to 0.008 percent (table 6), it is obvious that very little radioactive material occurs in the tailings. Samples of ore were collected and tested from various ore and concentrate bins in and near the mill. The maximum equivalent uranium content of any of these samples is 0.019 percent. The radioactivity is apparently associated with iron oxides in the ore. Table 6 lists the data on all the samples collected in and near the mill. Crystal shaft. -- The Crystal shaft (fig. 1) of the Nixon Fork mine is located in a highly metamorphosed zone of rock that probably includes both monzonite and limestone. About 50 feet northeast of the shaft a massive garnet rock underlies garnet-bearing, marmorized limestone and contains as much as 0.025 percent equivalent uranium. Study of samples from this locality (table 7) shows that the radioactivity is associated with garnet rock that is somewhat impure and weathered. The fresh, unweathered garnet is nonradioactive. The impurity in the garnet occurs in 
Table 6.--Data on ore, mill, and tailings samples from the Nixon Fork mine, 1949.

\begin{tabular}{|c|c|c|c|c|c|}
\hline \multicolumn{2}{|c|}{ Somples } & \multirow[b]{2}{*}{ Location and description } & \multirow{2}{*}{$\begin{array}{l}\text { Crushed rock } \\
\text { eU (percent) }\end{array}$} & \multicolumn{2}{|c|}{ Heavy-mineral fraction $2 /$} \\
\hline File no. & Field no. & & & eU (percent) & Concentration ratio \\
\hline 3542 & 49ASv 75 & Nixon Fork mill; mill tailings & -- & 0.002 & $1,950: 1$ \\
\hline 3543 & 76 & $\begin{array}{l}\text { Small stream along side of Nixon Fork } \\
\text { mine; mill tailings }\end{array}$ & -- & .004 & 370: 1 \\
\hline 3544 & 77 & Nixon Fork mine mill; mill tailings & -- & .003 & 590: 1 \\
\hline 3545 & 78 & Do. & -- & .008 & $3,400: 1$ \\
\hline 3546 & 79 & Do. & -- & .005 & 620:1 \\
\hline 3547 & 80 & Do. & -- & .004 & $120: 1$ \\
\hline 3548 & 81 & Do. & - & .002 & $1,360: 1$ \\
\hline 3549 & 82 & Do. & -- & .003 & $1,360: 1$ \\
\hline 3550 & 83 & Do. & -- & .002 & $560: 1$ \\
\hline 3551 & 84 & Do. & -- & .003 & $750: 1$ \\
\hline 3552 & 85 & $\begin{array}{l}\text { Nixon Fork mine mill; crushed ore, } \\
\text { partly concentrated }\end{array}$ & -- & .003 & ? \\
\hline 3553 & 86 & Do. & -- & .003 & ? \\
\hline 3554 & 87 & Do. & -- & .006 & ? \\
\hline 3555 & 88 & Do. & -- & .004 & ? \\
\hline 3556 & 89 & Do。 & -- & .004 & ? \\
\hline 3557 & 90 & Nixon Fork mine mill; mill tailings & -- & .002 & $1,360: 1$ \\
\hline 3559 & 92 & Do. & -- & .002 & $500: 1$ \\
\hline 3560 & 93 & Do. & -- & .002 & $2,700: 1$ \\
\hline 3561 & 94 & Do. & -- & .004 & 270:1 \\
\hline 3562 & 95 & Do. & -- & .002 & 450: 1 \\
\hline 3563 & 96 & Do. & -- & .002 & $210: 1$ \\
\hline 3564 & 97 & Do. & -- & .002 & $500: 1$ \\
\hline 3565 & 98 & Do. & -- & .003 & $900: 1$ \\
\hline 3566 & 99 & Do. & -- & .002 & $380: 1$ \\
\hline
\end{tabular}


Table 6.--Data on ore, mill, and tailings samples from the Nixon Fork mine, 1949--Continued.

\begin{tabular}{|c|c|c|c|c|c|}
\hline & amples & & Crushed rock & Heary - & eral fraction 2/ \\
\hline File no & Field no. & Location and description & eU (percent) ] & $\mathrm{eU}$ (percent) & Concentration ratio \\
\hline 3588 & 49AWe 81 & Nixon Fork mine; gold ore & 0.000 & 0.001 & 3: 1 \\
\hline 3589 & 82 & Nixon Fork mine; oxidized ore & .007 & .007 & $2: 1$ \\
\hline 3590 & 83 & Do. & .009 & .012 & $3: 1$ \\
\hline 3591 & 85 & Do. & .006 & .008 & $3: 1$ \\
\hline 3592 & 86 & Do. & .019 & .019 & $2: 1$ \\
\hline 3595 & 93 & $\begin{array}{l}\text { Nixon Fork mine; partly milled ore } \\
\text { from Garnet shaft }\end{array}$ & .002 & .006 & $?$ \\
\hline 3605 & 107 & $\begin{array}{l}\text { Nixon Fork mine; malachite ore from } \\
\text { Crystal shaft }\end{array}$ & .002 & -- & -- \\
\hline 3606 & 109 & $\begin{array}{l}\text { Nixon Fork mine; malachite ore from } \\
\text { Garnet shaft }\end{array}$ & .006 & -- & -- \\
\hline
\end{tabular}

1/ eU - equivalent uranium

2) that greatei than 2.8 specific gravity 
Table 7.--Data on samples of garnet rock from the vicinity of the Crystal shaft, Nixon Fork mine.

\begin{tabular}{|c|c|c|c|c|c|c|}
\hline \multicolumn{2}{|c|}{ Samples } & \multirow[b]{2}{*}{ Description } & \multirow{2}{*}{\multicolumn{2}{|c|}{$\begin{array}{c}\text { Crushed rock } \\
\text { eU (percent) } 1 / \text { U (percent) }\end{array}$}} & \multicolumn{2}{|c|}{ Heavy-mineral fraction $3 /$} \\
\hline File no. & Field no. & & & & $\mathrm{eU}$ (percent) & Concentration ratio \\
\hline 3610 & 49AWe 115 & $\begin{array}{l}\text { Surface wash on contact between } \\
\text { limestone and monzonite } 50 \text { feet } \\
\text { northeast of Crystal shaft; panned } \\
\text { concentrate }\end{array}$ & -- & -- & 0.014 & $270: 1$ \\
\hline 3611 & 116 & $\begin{array}{l}\text { Random fragments of garnet rock } \\
\text { showing high radioactivity }\end{array}$ & 0.018 & 0.008 & -- & -- \\
\hline 3612 & 117 & $\begin{array}{l}\text { Clean, unweathered garnet rock } \\
\text { from shaft }\end{array}$ & .000 & -- & -- & -- \\
\hline 3613 & 118 & Do. & .000 & -- & -- & -- \\
\hline 3614 & 119 & $\begin{array}{l}\text { Selected specimen of garnet rock } \\
\text { sh owing strongest radioactivity }\end{array}$ & .025 & .008 & -- & -- \\
\hline 3615 & 120 & $\begin{array}{l}\text { Garnet rock showing strong radio- } \\
\text { activity }\end{array}$ & .017 & .006 & .026 & $10: 1$ \\
\hline 3617 & 122 & $\begin{array}{l}\text { Monzonite at contact with garnet } \\
\text { rock }\end{array}$ & .003 & -- & .006 & $25: 1$ \\
\hline 3618 & 123 & $\begin{array}{l}\text { Same as sample } 3617 \text {; concentrate } \\
\text { obtained by pansing crushed rock }\end{array}$ & -- & -- & .012 & $60: 1$ \\
\hline
\end{tabular}


thin beds or irregular masses and is well coated with hydrous iron oxides. The composition of the garnet rock, exclusive of the hydrous iron oxides, is 65 percent garnet, 20 percent idocrase, 12 percent common rock-forming minerals, 3 percent sphene, and traces of zircon and magnetite. The radioactive minerals are idocrase and sphene. In a field inspection the radioactive material in the garnet appears to be mainly an iron-oxide coating and filling in fractures and fissures in the rock.

No significant radioactivity was detected at any of the numerous other prospect pits and shafts on the property of the Nixon Fork mine.

Other localities examined

Mystery, Puzzle, and Submarine Creeks

Three concentrates were collected from gravels in Mystery and Puzzle Creeks to supplement the samples from these creeks previously aroilable in the Alaskan Geology Branch concentrate file (table 1). The radioactivity of the three samples is given below:

\begin{tabular}{rrrrr}
\multicolumn{2}{c}{ Samples } & Location & \multicolumn{2}{c}{ Heavy-mineral fraction } \\
File no. Field no. & eU (percent) & Concentration \\
\hline 3571 & 49ASv 104 & Mystery Creek & 0.006 & $125: 1$ \\
3572 & 105 & Mystery Creek & .018 & $3,025: 1$ \\
3573 & 106 & Puzzle Creek & .003 & $130: 1$
\end{tabular}

Radiometric traverses were made around the heads of these two creeks as well as Submarine Creek, particularly along the ridge of which Strand and Jumbo Peaks are a part (fig. 1)。 No radioactivity anomalies were found.

\section{Eagle Creek}

Eagle Creek, a tributary of Crooked Creek, is located about 5 to 7 miles south of the Nixon Fork mines (fig. 1). B. A. Stone of Medfra operates a small gold- 
lode mine on the headwater slopes of the creek near the contact between the limestone country rock and a small monzonite mass. The heavy-mineral fraction (that greater than 2.8 specific gravity) of a sluice-box concentrate (sample no. 3642) from a placer operation on Eagle Creek owned by Stone contains 0.26 percent equivalent uranium. The mineral composition of the Eagle Creek sluice-box concentrate is given in table 5 . The radioactivity appears to be due chiefly to the uraniferous thorianite, although the allanite, hematite, and sphene are also radioactive. Radiometric traverses along the headwater slopes of Eagle and Skookum Creeks (fig. 1) failed to find the bedrock source of the radioactive minerals. A sample (no. 3644) of the monzonite on Eagle Creek contains only 0.003 percent equivalent uranium and a sample (no. 3643) of garnet rock from the lode mine contains less than 0.001 percent equivalent uranium. Again, however, the negative radiometric data obtained in traversing is not conclusive because of the thick vegetation cover over most of the area.

In 1950 a placer concentrate containing 0.18 percent equivalent uranium and 0.06 percent uranium was received from a prospector, who indicated only that it came from western Alaska; information obtained later suggests that it is probably from a placer mine in the Nixon Fork district. The mineralogy of this sample (no. 3850) is compared with two other placer concentrates from the Nixon Fork district in table 5. The marked similarity of this concentrate to that from Eagle Creek (no. 3642) suggests the probability that it also is from Eagle Creek rather than elsewhere in the district. Of note is the occurrence of uraninite as well as the uraniferous thorianite. 


\section{SUMMARY AND CONCLUSIONS}

A summary of significant radioactivity data obtained in the Nixon Fork mining district in 1949 is given in table 8 . The only radioactive mineral of major importance is uraniferous thorianite, although such minerals as allanite, parisite, idocrase, sphene, zircon, malachite, and two unidentified secondary polymetal minerals are also radioactive. Uraninite has been identified in a concentrate that may have come from a placer mine in the district. The bedrock source of the uraniferous thorianite has not been located, but is believed to occur, at least in part, in a restricted zone or zones at or near the contact between limestone and monzonite similar to the gold-copper ores of the district and the radioactive parisite zone at the Whelan mine and the radioactive garnet rock zone at the Crystal shaft of the Nixon Fork mine.

Search for bedrock sources of the radioactive minerals in the district by radiometric surveying is hampered considerably by the shielding effect of the heavy moss cover so prevalent through much of interior Alaska.

It is suggested that geochemical prospecting techniques, such as the analysis of samples of disintegrated material taken from auger holes through the shielding moss cover may prove more successful in locating the bedrock source of the uranium- and thorium-oxide minerals than surface radiometric traversing. Such sampling might well be supplemented by the radiometric logging of the auger holes with a survey meter such as a portable scaler. Much study on the application of geochemical prospecting techniques in Arctic and sub-Arctic regions is needed, however, before a routine can be developed. 
Table 8.--Summary of significant radioactivity data obtained in the Nixon Fork mining district, 1949.

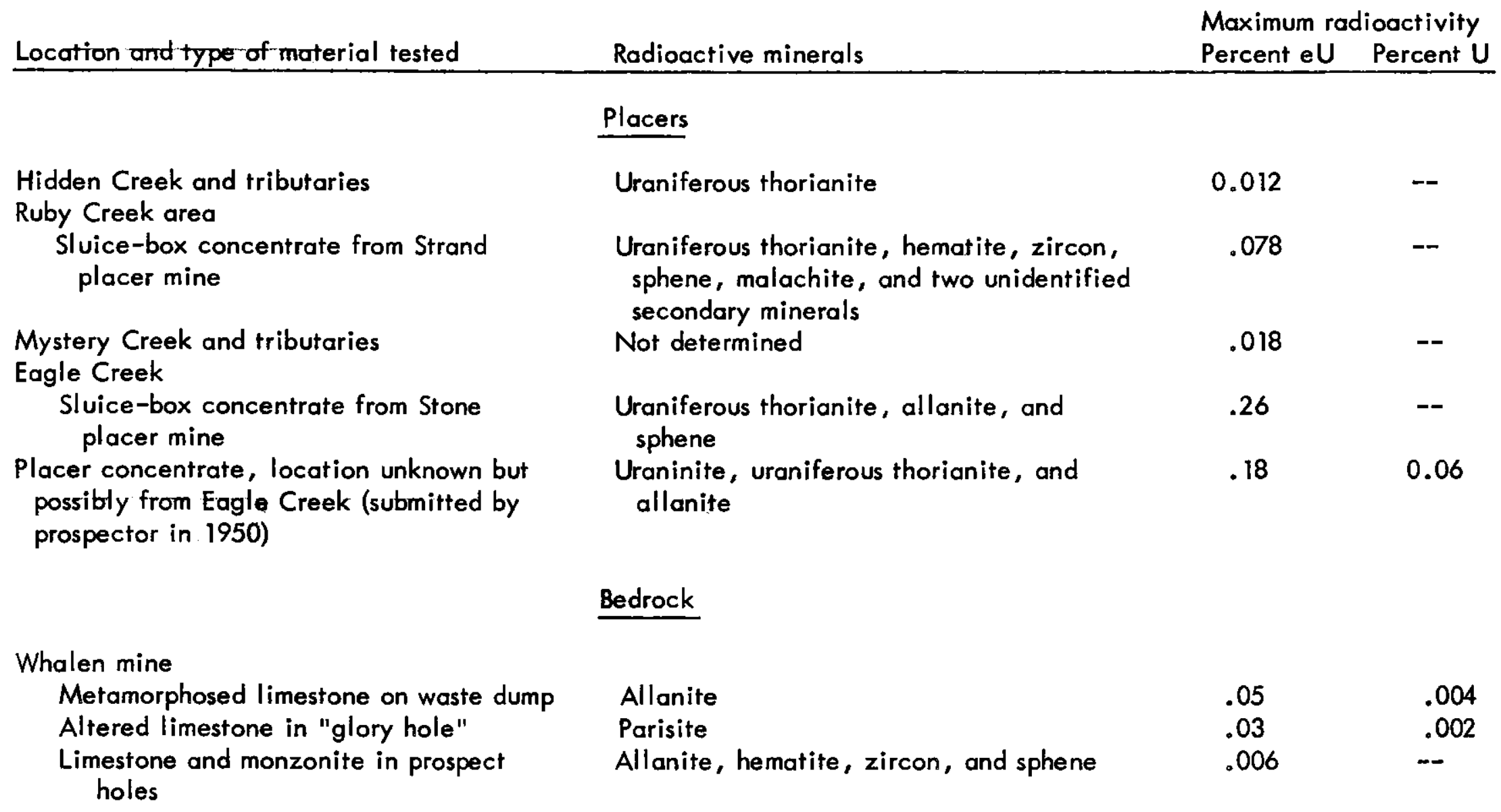


Table 8.--Summary of significant radioactivity data obtained in the Nixon Fork mining district, 1949--Continued.

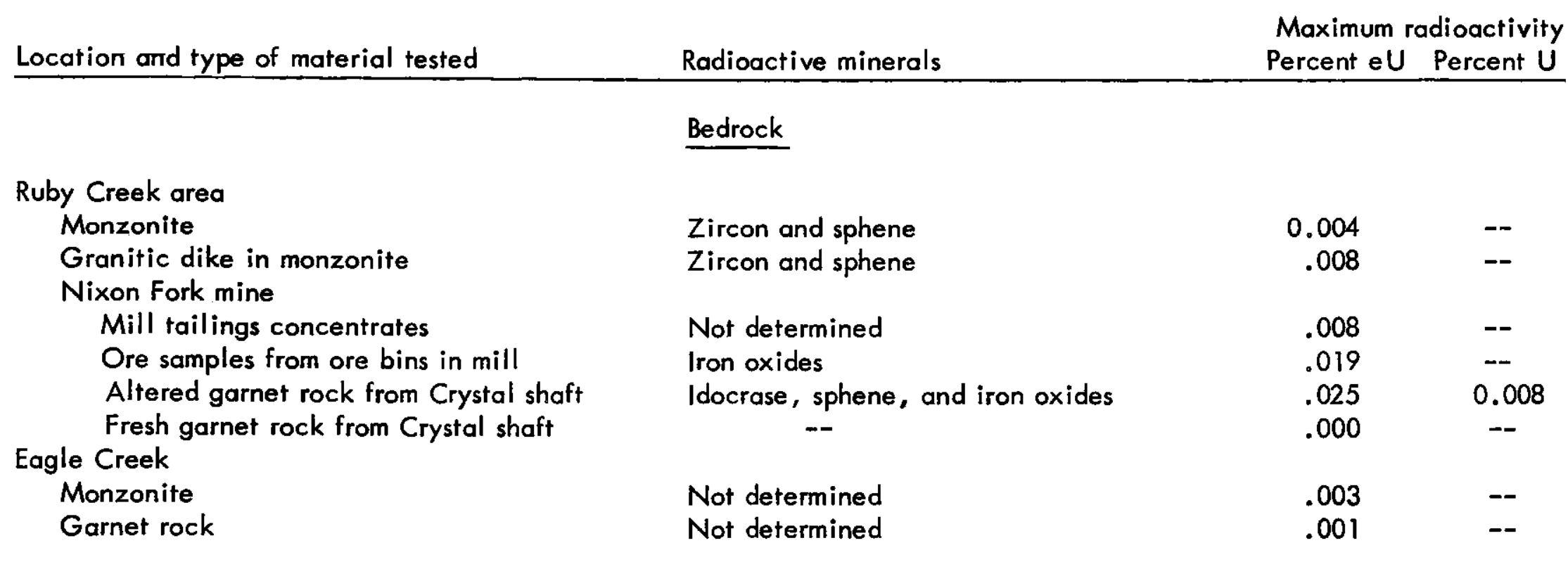




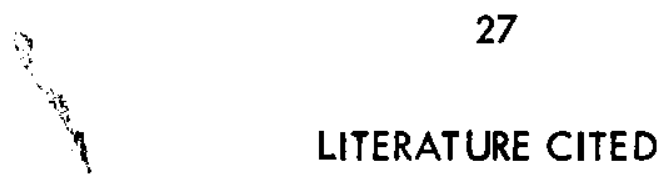

Brown, J. S., 1926, The Nixon Fork country and silver-lead deposits near Ruby (Alaska): U. S. Geol. Survey Bull. 783-D, pp. 97-150.

Martin, G. C., 1922, Gold lodes in the upper Kuskokwim region (Alaska): U. S. Geol. Survey Bull. 722-E, pp. 149-161.

Mertie, J. B., Jr., 1936, Mineral deposits of the Ruby-Kuskokwim region (Alaska): U. S. Geol. Survey Bull. 864-C, pp. 115-255. 
UNITED STATES

DEPARTMENT OF THE INTERIOR

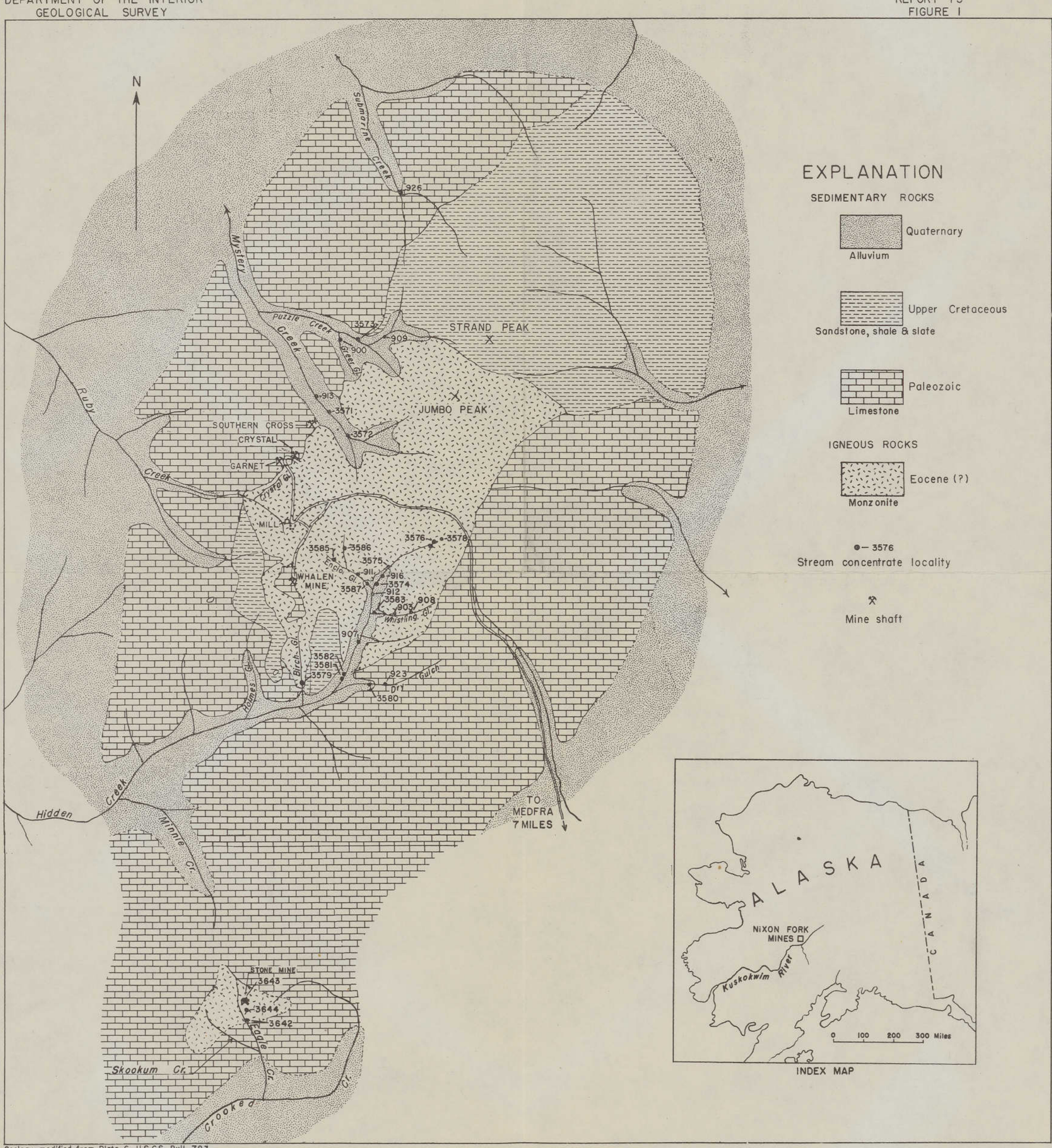

GEOLOGIC SKETCH MAP OF THE VICINITY OF THE NIXON FORK MINES 


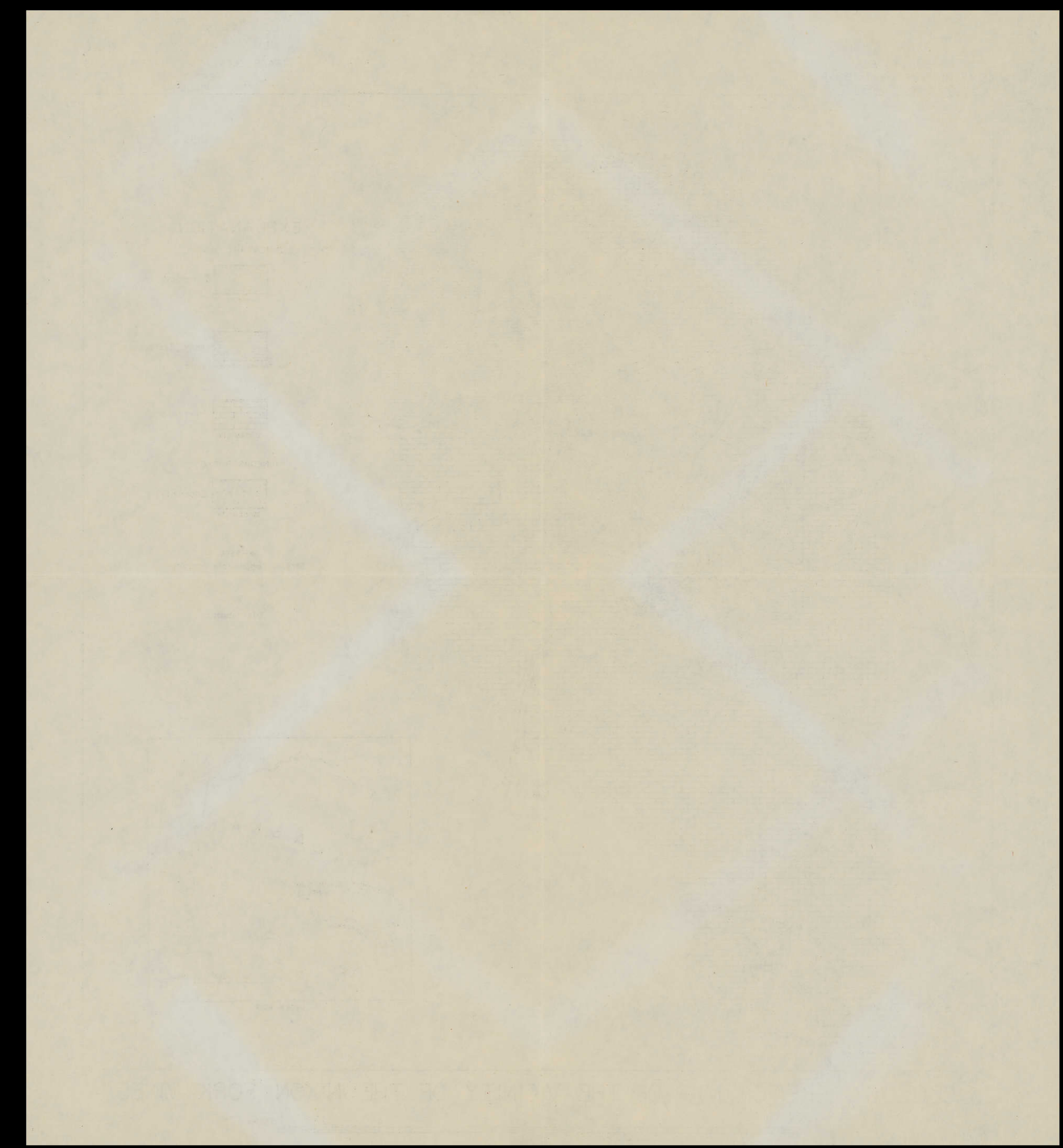

